\title{
IL11 wt Allele
}

National Cancer Institute

\section{Source}

National Cancer Institute. IL11 wt Allele. NCI Thesaurus. Code C49789.

Human IL11 wild-type allele is located within 19q13.3-q13.4 and is approximately $6 \mathrm{~kb}$ in length. This allele, which encodes interleukin-11 protein, is involved in cellular development, proliferation and signal transduction. 